\title{
Menumbuhkan Rasa Semangat Siswa Saat Pembelajaran Daring Melalui Lagu Indonesia Raya
}

\author{
Siti Nurjanah \\ E-mail: siti.nurjanah2466@student.unri.ac.id \\ * Program Studi Pendidikan Bahasa dan Sastra Indonesia, Universitas Riau
}

\section{Pengantar}

Keadaan pendidikan di Indonesia saat ini dilakukan secara daring, hal ini dikarenakan virus covid-19 menyebar luas hampir di seluruh Indonesia bahkan dunia. Pembelajaran secara daring merupakan inovasi pendidikan yang dapat dilakukan dimasa sekarang, dengan pembelajaran daring para siswa tetap dapat belajar tanpa harus pergi ke sekolah yang mana hal ini juga dapat meminimalisir penyebaran virus covid-19. Dengan pembelajaran daring ini dapat mengasah skill para siswa dalam memanfaatkan teknologi, hal ini dikarenakan pembelajaran daring sangat memerlukan penguasaan tentang teknologi yang tinggi. Namun tidak sedikit juga para siswa yang merasa bahwa pembelajaran daring ini dianggap kurang efektif dan efisien.

Pada pembelajaran daring sering kali siswa merasa jenuh dan mudah bosan, bahkan pada awal pembelajaran. Ketika siswa merasa jenuh tentunya akan mempengaruhi proses pembelajaran yang berlangsung. Selain itu akan mempengaruhi pemahaman materi yang diberikan oleh guru. Ketika siswa kurang memahami materi maka nantinya akan berdampak pada nilai dan hasil akhir yang akan dicapai siswa. Untuk menumbuhkan rasa semangat guru dapat melakukan berberapa hal yang bisa menumbuhnkan semangat pada diri siswa., misalnya mengajak siswa untuk menyanyikan lagu Indonesia Raya di awal pembelajaran. Selain menimbulkan rasa semangat lagu Inodonesia Raya juga dapat menguatkan rasa akan cinta tanah air dan nasionalisme pada diri siswa. Menumbuhkan rasa semangat pada siswa merupakan suatu hal yang sangat penting dilakukan oleh guru. 


\section{Tindakan yang Dilakukan}

Untuk menumbuhkan rasa semangat siswa menggunakan lagu Indonesia Raya, membutuhkan beberapa tindakan yang di lakukan oleh guru. Guru adalah orang yang sangat berjasa, ia memberikan ilmu yang ia miliki kepada siswanya. Guru membantu orang tua dalam mengajri anak-anak mereka mengenai berbagai hal yang tentunya akan berguna bagi anak-anak tersebut. Kehadiran guru sangat diperlukan untuk kelancaran aktivitas pembelajaran yang dilakukan. Menurut Zulhafizh (2013) guru merupakan orang yang dapat memberikan pencerahan dan pemahaman tentang moral ataupun spiritual kepada siswa.

Guru perlu menyiapkan diri sendiri dan juga siswanya. Kesiapan guru dan siswa ini sangat penting agar kegiatan yang dilakukan dapat terlaksana dengan baik. Ketika guru dan siswa kurang siap atau bahkan belum siap nantinya tujuan dari kegiatan ini akan tidak terlaksanakan secara maksimal. Sehingga guru tidak dapat menumbuhkan rasa semangat pada siswa-siswanya. Kesiapan siswa juga dapat mendukung dalam proses belajar mengajar yang akan dilaksanakan dan tentunya mempengaruhi prestasi belajar siswa. Ada hubungan pada tingkat koefisien korelasi cukup kuat antara kesiapan belajar siswa dengan prestasi belajar siswa (Mulyani D, 2013)

Langkah selanjutnya adalah menyiapkan video lagu Indonesia Raya. Tentunya untuk menumbuhkan rasa semangat siswa melalui lagu Indonesia Raya diperlukan video lagu itu sendiri. Hal ini untuk mendukung atau membantu para siswa yang tidak hafal lagu Indonesia raya, namun selain itu juga agar siswa lebih tertarik untuk ikut serta menyanyikan lagu indosesia raya. Dengan menampilkan video lagu Indonesia Raya maka siswa akan lebih fokus.

Lagu Indonesia Raya adalah lagu kebangsaan yang di dalamnya terdapat semangat dan cita-cita para pahlawan. Lagu ini diciptakam oleh WS Supratman, beliau adalah salah satu pahlawan nasional. Menyanyikan lagu kebangsaan Indonesia Raya ialah salah satu wujud dari upaya kecintaan terhadap tanah air negara Indonesia dan salah satu implementasi dari sikap nasionalisme atau cinta 
tanah air. (Nurul Annisa, Hasibuan Puan Hidayati, dan Siregar Eko Febri Syahputra, 2020 ).

Langkah terakhir yang dapat dilakukan adalah memerintahkan siswa untuk menyanyikan lagu Indonesia Raya. Ini merupakan langkah penentu dalam menumbuhkan rasa semangat pada siswa. Saat siswa bernyanyi lagu Indonesia Raya, maka mereka akan menghayati liriknya. Di dalam lirik lagu Indonesia Raya terdapat semangat dan cita-cita para pahlawan. Semangat dan cita-cita para pahlawan tersebut akan menimbulkan rasa semangat dan cinta tanah air pada diri siswa.

\section{Sarana Pendukung}

Tak hanya tindakan oleh guru yang diperlukan dalam menumbuhkan rasa semangat melalui lagu Indonesia Raya. Tetapi sarana pendukung juga turut menjadi unsur penting. Pada saat kondisi negara Indonesia yang tengah dilanda Virus Covid-19, proses belajar mengajar dilaksanakan secara daring. Pembelajaran daring tentunya adalah hal yang baru bagi siswa, sehingga siswa perlu penyesuaian diri.

Pembelajaran daring adalah pembelajaran yang dilakukan dalam jaringan atau bisa disebut pembelajaran jarak jauh. Untuk melaksanakan pembelajaran secara daring siswa memerlukan skill agar pembelajaran daring dapat terlaksana secara optimal. Menurut zulhafizh (2020) Di masa covid-19, aktivitas belajar mengajar dilakukan melalui daring sehingga membuat mahasiswa belajar secara mandiri dan melatih skilnya agar dapat mencapai tujuan pembelajaran. Mahasiswa dan siswa sama-sama orang yang tengah mencari ilmu, namun perbedaanya pada tingkatan. Dengan adanya pembelajaran daring ini secara tidak langsung akan mengasah skill yang dimiliki siswa.

Menumbuhkan rasa semangat siswa pada pembelajaran daring melalui lagu Indonesia Raya membutuhkan beberapa sarana pendukung. Sarana ini dapat membantu untuk mencapai tujuan yang di inginkan. Beberapa sarana tersebut adalah sebagai berikut: 
1. Google Meet. Google meet adalah sebuah layanan komunikasi video yang dikembangkan oleh google. Untuk bergabung ke rapat/kelas online menggunakan Google Meet dapat dilakukan dengan mudah, yaitu menggunakan akun google. Aplikasi ini pun dapat digunakan baik di laptop atau di handphone, sehingga memudahkan siswa ketika siswa tidak mempunyai laptop maka bisa menggunakan handphone dan sebaliknya.

2. Zoom. Zoom adalah aplikasi komunikasi menggunakan video. Aplikasi ini dapat digunakan untuk belajar maupun rapat secara online. Sama halnya dengan Google Meet aplikasi zoom ini dapat digunakan menggunakan laptop dan handphone. Tentunya aplikasi satu ini dapat membantu untuk melakukan pembelajaran secara online

3. Laptop/Handphone. Laptop atau handphone merupakan alat komunikasi. Aplikasi-aplikasi di atas dapat digunakan jika sarana pendukung ini ada.

4. Kuota Internet. Kota adalah jumlah dari muatan data yang bisa digunakan pada jangka waktu tertentu. Kuota internet merupakan hal yang dibutuhkan untuk menjalankan aplikasi pembelajaran. Tanpa kuota internet maka aplikasi pembelajaran tidak dapat digunakan.

5. Jaringan. Untuk menggunakan aplikasi pembelajaran, alat komunikasi, dan kuota internet memerlukan jaringan. Sama halnya dengan kuota internet tanpa jaringan maka sarana pendukung tersebut tidak akan dapat digunakan.

6. Grup WhatsApp. Grup WhatsApp merupakan fitur yang diberikan oleh aplikasi WhatsApp. Aplikasi whatsapp sendiri merupakan aplikasi mengirim pesan dan melakukan panggilan. Aplikasi ini dapat digunakan oleh guru untuk memberikan informasi atau memberikan link Google Meet/Zoom untuk pembelajaran daring.

7. Dan lain-lainnya 


\section{Tindakan Solutif}

Selain sarana tindakan yang dilakukan dan sarana pendukung, guru harus bisa sigap dalam menghadapai kendala yang terjadi. Guru harus menyiapkan solusi terhadap kemungkinan-kemungkinan yang dapat menjadi penghalang dalam proses proses belajar mengajar. Solusi ini berguna untuk meminimalisir terkendala nya sebuah proses belajar mengajar yang dilakukan. Ketika sebuah proses belajar mengajar terkendala maka pembelajaran tidak akan terlaksana secara efektif.

Dalam sarana pendukung di atas tentunya memiliki kendala. Tindakan solutif yang dapat dilakukan guru ketika terjadinya kendala ialah sebagai berikut. Ketika aplikasi Google Meet terkendala, maka guru dapat menggantikannya menggunakan aplikasi zoom. Aplikasi zoom dapat dijadikan pengganti Google Meet karena 2 aplikasi ini merupakan sebuah aplikasi komunikasi menggunakan video. Begitu pula sebaliknya, jika aplikasi zoom terkendala maka dapat digantikan menggunakan aplikasi Google Meet.

Ketika siswa tidak memiliki perangkat komunikasi seperti laptop dan handphone, maka siswa dapat membeli perangkat tersebut. Selain itu siswa juga dapat meminjam perangkat komunikasi milik orang tua atau saudaranya. Namun jika itu juga tidak bisa dilakukan, siswa dapat menyewa perangkat elektronik di warnet (warung internet).

Kuota internet merupakan salah satu satu sarana yang wajib ada. Harga kuota internet yang begitu mahal membuat beberapa orang tua tidak dapat membelinya. Namun hal tersebut mempunyai solusi, siswa dapat menggunakan Wi-Fi milik tetangga, saudara, Wi-Fi gratis yang disediakan oleh beberapa fasilitas umum. Sama halnya dengan kuota internet jaringan sangat mempengaruhi pembelajaran daring. Ketika siswa mengalami kendala jaringan yang tidak stabil, maka solusi yang dapat dilakukan ialah siswa mencari tempat lain yang memiliki jaringan stabil.

Sarana pendukung selanjutnya adalah grup WhatsApp. Aplikasi WhatsApp merupakanan sebuah aplikasi yang banyak digunakan. Ketika aplikasi WhatsApp mengalami kendala, maka solusi yang dapat dilakukan adalah 
menggunakan aplikasi telegram. Aplikasi telegram dapat dijadikan pengganti atau solusi dikarenakan memiliki fungsi yang tidak jauh beda dari aplikasi WhatsApp. Itulah beberapa solusi yang dapat dilakukan oleh guru ketika sarana pendukung mengalami kendala.

\section{Simpulan}

Rasa semangat pada siswa dapat berpengaruh dengan proses belajar mengajar secara daring, bahkan berpengaruh pada pemahaman atau hasil akhir yang akan di dapat siswa. Semangat ini dapat tumbuh dengan cara menyanyikan lagu Indonesia Raya pada awal pembelajaran. Karena ketika siswa menyanyikan lagu Indonesia Raya, mereka akan menghayati lirik. Di dalam lirik lagu Indonesia Raya terdapat rasa semangat dan cita-cita para pahlawan. Tentunya rasa semangat dan cita-cita para pahlawan ini dapat menumbuhkan rasa semangat serta cinta tanah air pada diri siswa.

Hal diatas dapat terlaksana dengan cara guru melakukan tindakan. Selain tindakan, menumbuhkan rasa semangat siswa pada pembelajaran daring melalui lagu Indonesia Raya dapat dilakukan dengan sarana pendukung. Sarana pendukung ini berupa aplikasi-aplikasi yang dapat dimanfaatkan dalam proses belajar mengajar secara daring. Sarana pendukung ini juga akan menimbulkan kendala-kendala. Namun kendala-kendala tersebut dapat diatasi menggunakan tindakan solutif yang dilakukan oleh guru.

\section{Referensi}

Zulhafizh, Z. (2020). Membina Aktivitas Belajar Mahasiswa di Perguruan Tinggi Melalui Metode TIE (Translation, Interpretation, Extrapolation) pada Masa Pandemi Covid-19. Jurnal Kependidikan: Jurnal Hasil Penelitian Dan Kajian Kepustakaan Di Bidang Pendidikan, Pengajaran Dan Pembelajaran, 6(3), 502. https://doi.org/10.33394/jk.v6i3.2865

Zulhafizh, S.Pd., M. P. (2013). Guru: Profesi Yang Tak Lekang Oleh Waktu. Dialog Interaktif Profesi Kependidikan, 1-11. 
Annisa, N., Hasibuan, P. H., \& Siregar, E. F. S. (2020). Singing Indonesia Raya As Shaping of Implamentation of the Reinforcement of Education Character. EJoES, 1(1), 1-3.

Mulyani, D. (2013). Hubungan Kesiapan Belajar Siswa Dengan Prestasi Belajar. Konselor, 2(1), 27-31. https://doi.org/10.24036/0201321729-0-00 


\section{*Data Penulis}

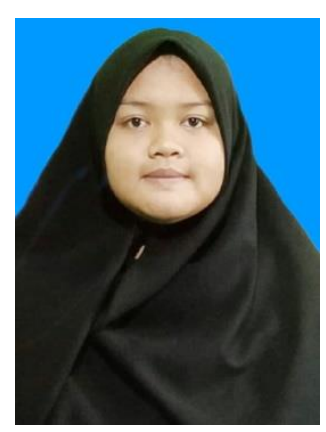

Siti Nurjanah, lahir di Sungai Siput, 26 Agustus 2002. Pada tahun akademik 2020-2021 ia melanjutkan studi pada salah satu Jurusan Pendidikan Bahasa dan Seni di Program Studi Pendidikan Bahasa dan Sastra Indonesia FKIP Universitas Riau melalui jalur SBMPTN (Seleksi Bersama Masuk Perguruan Tinggi). Ia mendapatkan rangking lima besar ketika duduk dibangku SMA.

Kontak:

Hp/WA : 085264154105

Email : siti.nurjanah2466@student.unri.ac.id 